\title{
History in Contemporary Lithuanian Literature
}

\author{
AUDINGA PELURITYTÉ
}

\begin{abstract}
The purpose of this article is to show the evolution of the historical novel that began in the era of independence, to highlight the peculiarities of male and female historical narratives, and to capture critical reactions and tendencies of assessment of that kind of novel. At the beginning of independence, the poetic prose of a minimal story was established in Lithuanian literature, which was created by the most prominent Lithuanian prose writers, and the historical novel made its debut as a complex experience of poetic narration. Poetry and prose focused on archetypal narratives, national consciousness and ethnic semantics and were characterized by an abundance of associations, but not by a clear storyline. Among common variations of the male historical novel, we can observe historical novels written by women, which have won both literary awards and readers' approval.
\end{abstract}

Keywords: historical novel; prose poetry; national self-awareness; the beginning of independence; association and metaphor; male and female version

\section{Arguments for the Emergence of Prose Poetry}

In the early 1940s, Lithuanian literature felt as if it were a newborn baby with no name and no family, as if it belonged to a nation with no qualities, by analogy with the name of the novel The Man Without Qualities by Robert Musil. Deprivation of national memory left a deep mark on Lithuanian literature, taking away its experience of the realization of the European time and cultural and personal achievements. Creation of a new man and a new epoch (i.e. communism) by the Soviet Union required removal of everything that there was in the occupied geographical and mental territory so that a new history could be built.

What was required of the art itself by the totalitarian system was not evidence (which was irrefutable), but rather approval, a demonstration of loyalty, and some sort of explanation of principles of historical truths understandable in terms of natural science: "Facts that do not correspond to principles are meaningless, just like incomprehensible words in a language, and they are not, therefore, historical, they 'do not exist' " (Šilbajoris 1992: 509). Within a couple of decades during the first independence, national self-awareness, which was suppressed by a 
single "truth", in this way suppressed the reflection of national identity, the fact of being different from other nations, and historical achievements, which had been created by historical development.

The Soviet perspective "friendship between nations" essentially equalised historical self-awareness of all the annexed countries, and this equalisation was demonstrated not only by uniform heraldry, national costumes, lifestyle, but also by the "truth" of a single history told in history textbooks. The class conflict scheme served as the main version of such a "truth", where the heroes were Soviet workers and peasants; they removed the ruling class and their values from the historical scene using brutal weapon power. The fact that a mass of poorly educated people became ideologists of civic values could not be unsurprising or nonintimidating to European societies at the time, but the annexed nations' literature was aimed at forcibly convincing those who did not believe that it was appropriate and good. Literature had to put these marks into words, to fuse them into a single narrative, whose diversity of plots was unfortunately restricted by ideological dialectics of the "truth".

The political enticement, repression and reward schemes for authors are depicted in the book The Captive Mind (1953) by the Lithuanian-Polish poet and intellectual Czeslaw Milosz (1911-2004) and today there are not that many European intellectuals who are not familiar with this work, so I will not refer to it again ${ }^{1}$. Examples of such false heroes could be cited as a separate fact; being real people, they were turned into icons of the new truth as they represented the ideals of the Soviet empire in their fight for the Soviet truth and faced terrible fates, and they lost their lives in a supposedly conscious fight for the ideals of a new history. One of them was Marytė Melnikaitè (Lithuanian, 1923-1943), who became a character in a poem by Salomejja Nèris (born Salomèja BačinskaitèBučienè, 1904-1945) and an example of heroism in the early Soviet period, and Leen Kullman (Estonian, 1920-1943), who, most likely, did not even die but went to live in Germany and became a heroine of many documentary plots and pro-Soviet legends in Estonia.

Famous authors' names were necessary in order to lay the foundations for the new system as the power of words spoken by recognised authorities, who were often respected by society, was much more influential than of those spoken by unknown new ideologists. At the time, the head of the publishing house that published the book against Salomeja Neris's will and distorted the original conception was a well-known employee of the NKVD (the People's Commissariat for Internal Affairs) and Head of the Soviet Union security

Today the notion of "ketman" adapted to the Soviet lager helps to evaluate the degree of responsibility of an artist as a citizen. 
structures in Lithuania Aleksandras Gudaitis Guzevičius (1908-1969). The author, who was still unknown, was writing a voluminous epic work Kalvio Ignoto teisybe (Blacksmith Ignotas' Truth, 1949), which was immediately published and awarded the greatest prize at the time, i.e. the Stalin Prize. The two-volume novel, full of proletarian ideology, had nothing to do with the structure of the Lithuanian rural setting and Lithuanian mentality in general, but it conformed perfectly to the norms of the declared "truth".

Essentially, the novel Blacksmith Ignotas' Truth distorted the real Lithuanian history by creating its illusory version necessary for the totalitarian system with the help of socio-realist fiction. As if it were a simplified version of Christian history, this distorted history proclaimed the beginning of a new era built on the foundations of the old world and the new man's sacrifice. However, history cannot be built without time. The mechanism of the Christian timeline, and its socio-realist interpretation, according to Isaiah Berlin (Berlin 1995: 132-162), turned the version of implementation of the totalitarian Soviet utopia into history without history and without time. The idea of social realism, assigned to Zhdanov by Stalin himself and submitted to the press in the 1920s, was not only a form of propagandist art, but also a tool used for shaping the world. The role of criticism was to monitor and to adapt.

Today it is difficult to find a suitable notion to define the atmosphere which writers and literary critics lived in during the period of early totalitarianism because only today can the mixture of natural horror and coercive joy be defined through absurdity, grotesqueness, or logical paradox. One of the most complex tasks of the doctrine of social realism was to eliminate the philosophical meaning of history, i.e. the metaphysical content of human existence. And it was more difficult to evade not a socio-realist but a deeper dimension of time in epic works than it was in poetry. However, the beginning of the Aesopian language may also be considered to be a return by Lithuanian literature to the art of poetry. Removal of the European and national memory meant not only the obliteration of history, but also inability to draw on one's own experience in time.

One of the biggest traumas experienced during the five decades of totalitarian coercion, when people had to put up with heavy casualties and which Lithuanian literature faces even today, is the trauma of losing the history pulse, memory and responsibility for one's own history. During the decades of the first independence, national self-awareness flourished and national history and national self-respect were a popular topic. The whole younger generation were brought up to have dignified national self-awareness and most people who belonged to it were part of a resistance movement in dreadful conditions under occupation. Those who fought in the partisan war belonged to this generation. One of the deepest marks left by the trauma that is felt today is lack of historical truth and historical novels 
in Lithuanian literature, especially when we talk about memories of the period of the Soviet Union, the partisan war and resistance.

Indeed, so far the events of the partisan war have not been adequately reflected in any outstanding work - neither cinematic, artistic, nor literary. We could say that under totalitarian occupation conditions the narrative of national self-awareness was interrupted as the real truth could not be told by people of any generation under social realism conditions, and the generation of partisans did not have the possibilities for creating epic narratives. All that is left are the collections of poems by Bronius Krivickas (1919-1952) and Diana Glemžaitè (1925-1949) published at the beginning of restored independence, which tell us about good results regarding Lithuanian poetry and the deceased young authors' talent. During as few as five decades (if we count the years of the first and the second independence), Lithuanian literature made its debut and tried to establish itself through stronger positions of poetic art. The prevalent lyrical poetry rested on the foundations of the first independence and established mental identity structures.

Lithuanian-born American phenomenologist Algis Mickūnas talked about the meditative, almost Zen character of Lithuanian singing folklore and Lithuanian poetry, to which he attributes an exclusively sensory Zen imagination (Mickūnas 2012: 67). Although Lithuanian prose developed rapidly during the period of the first independence, narrative prose caused problems due to its talented representatives collaborating with the Soviet system after Lithuania gained its independence. Only today does Lithuanian literature see more interesting science fiction, or rather magical fiction works, which cannot be said about detective stories. After the independence was regained, a good, realistic, psychologized prose narrative by Petras Cvirka (1909-1947) and Juozas Baltušis (1909-1991), particularly popularised during the Soviet times, compromised itself due to both the authors' loyalty to the totalitarian system and quite a few lies in their works of the Soviet period.

\section{The Flourishing of Prose Poetry}

The authors who had compromised themselves compromised, in their own way, the prose narrative too, together with a clear storyline which tells us about people's fates and general national history. In the late Soviet times, retreat from storytelling was conscious and a new kind of prose narrative - metaphorical, poetic, reflective - came to talented storytellers' rescue. Only during the third decade of its restored independence did Lithuanian literature regain its gift of creating narrative, and if we look at its most mature examples from the late Soviet times, the 1970s and 1990s, we can see it was prose narrative, which 
viewed history as a phenomenon not in terms of time but some kind of mythical eternity. The experience of the best meditative poetry permeated Lithuanian prose and became its modus vivendi. It also became a solution for poetics to resist censorship - a form of the Aesopian language.

Romualdas Granauskas (1939-2014) and Juozas Aputis (1936-2010), who started to write prose of great aesthetic power in Soviet times, won the readers' hearts with their works filled with ethnic self-awareness, whose characters' inner reflection started to be favoured over a narrative with a storyline. Associative writing was based on the revelation of the Baltic archetype and the agricultural character psychotype in the modern world. A strong metaphor filled with mythical and archetypal content set a good example of Lithuanian prose that did not please the norms of social realism, and the most talented Lithuanian prose writers followed this example. At the beginning of independence, they were joined by poet and artist Leonardas Gutauskas (b. 1936), who belonged to the same generation and who wrote ten outstanding prose poetry books during the first decade, and by Marius Ivaškevičius (b. 1973), younger by two generations, whose ambitious prose poetry experiment embodied an ambition to tell a complex story about the partisan war by using poetic associations.

Lithuanian prose poetry, which abandoned narratives with a storyline and established moral and aesthetic authority, determined the development of Lithuanian prose for a long time. Associations, metaphors and archetypes became one of the most significant features of a modern Lithuanian narrative, usually referring to an unimportant dimension of time - the history and prehistory of the Balts, a universal and magical dimension of time, and a recurrent psychological or mythical cycle of time. Lithuanian poetry followed the same path, and painting, graphic arts and poetic Lithuanian cinema concurrently created the same associative narratives, so the prose exploring the theme of ethnic individuality naturally branched into magical realism prose narrative by Saulius Tomas Kondrotas (b. 1953) or Jolita Skablauskaitè (1950-1918), and into psychological realistic minimalist prose by Bitè Vilimaitè (1943-2014) or Antanas Ramonas (1947-1993); however, in all the different solutions the real historical background predominated.

Associations, archetypes and pauses, substituting for an unspoken timeline of events, eventually became not only a specific skill of the Aesopian language, but also an established norm in narratives. A clear, developed and logical plot was the price Lithuanian prose had to pay for the survival of free thought, but this does not mean that history, time or the present did not matter to Lithuanian prose writers at all. They did, but when Lithuanian prose poetry emerged and flourished, this did not result in a long narrative - it was expressed using a new form of realistic prose, i.e. realistic psychological prose. That was a new kind of 
prose poetry, which created a storyline using complex psychological conflicts and polysemous pauses of silence. A distinctive feature of such prose was the shortness of works, and prose writer Bite Vilimaite is regarded as a pioneer of it. Literary critic Albertas Zalatorius pointed out a special play of semantic polysemy and pauses in Bitè Vilimaitè's prose (Zalatorius 1988: 191).

Bitè Vilimaitës short stories, which are astounding and focus on topical subjects and are very short indeed, have become a school of Lithuanian prose. Its most prominent representatives of the younger generation, Danute Kalinauskaite (b. 1959) and Daina Opolskaite (1979), are among the most valued prose writers in Lithuania today. Bité Vilimaite simply depicted the general tendency the most vividly, but there were a few more authors who also aimed for something similar at the same time: Vanda Juknaite (b. 1949), who viewed the development of psychological conflicts within the context of society's social problems and actualised and analysed them skilfully in her works, and the already mentioned Antanas Ramonas, who focused on short narratives, pauses, details, psychological conflicts and Lithuanian history - the Grand Duchy of Lithuania and the city of Vilnius.

The flourishing of Lithuanian prose poetry determined the vertical method of poetry reading by Roland Barthes (Barthes 1991: 45). The reader felt the need to read pauses and associations and understand what was between the lines. Such writing and reading created special relations of trust, which were not created by the authors recognised by conjuncture who told stories of social realism, and therefore their names were forgotten and the publication of their abundant works ceased after independence was restored. The special empathy created by prose poetry matched the great artistic mastery, so such a way of speaking, unsurprisingly, established itself and became dominant and fashionable. Using associations and ellipses slowly became such a common way of expression that newly emerging authors started to carry out their experiments within the norms of prose poetry. For example, one of the most interesting and the most read authors of recent decades Valdas Papievis (b. 1962) radically innovated realistic psychological prose, and essentially prose poetry by shifting, very consciously, the play of associations and ellipses from semantics to syntax. The fact that he had studied modern French novels at Sorbonne University and had a deep knowledge of French also played an important role in this case.

Attempts to reflect on one's own thinking and mentality actually started together with the evolution of Lithuanian prose poetry, which closely associated its links to reality with psychological psychoanalysis of the environment and community. Unsurprisingly, probably the best author of historical narrative Petras Dirgèla (1947-2015) implemented his historiosophical concept of Lithuanian history on the principle of such meditative narrative, and the most mature 
work reflecting this is probably the epic he wrote after independence had been regained. The series of novels Kingdom: An Epic of Earth Travellers (four books: 1997-2004) is an example of Lithuanian prose poetry. Dirgèla was interested in the philosophical side of history, so he chose to tell stories about real events along with events that could have happened but did not due to chance, which was one of the more interesting features in his work.

Dirgèla's prose poetry developed the idea of a transcendental Lithuania based on a transformation of reality into a higher reality, a myth of life. The question of Lithuanian history and statehood is one of the cornerstones that stemmed from the poetry of the Aesopian language, which explored its deep Indo-European self-awareness in a broad context of world religions and history. One of the most important features of this self-awareness is the idea that life, history and reality started with a dream, a vision, which is also seen in the legend of the founding of Vilnius; and the shamanic version of such a vision is told by one of the oldest Baltic myths - the myth of Sovijus, where signs coming from a dream indicate the norms and rituals of the presence of reality in time (Beresnevičius 1990: 7284 ), and in the foundations of these rituals were the origins of Indo-Europeans' metaphysical thinking (Beresnevičius 2008: 144-145).

Literary scholars and philosophers who analysed Dirgèla's ideas of transcendence of Lithuanian history stress the multi-layered scope of intellectual conception, where the author attempts to combine life with a dream, history with transcendence, the possible with the impossible. A professional writer, historian or philosopher does not question the value of such a scope (the epic Kingdom comprises 14 novels) in reflecting both the dreams of the intellectuals of that time to see the meaning of Lithuanian history (Bartninkas 2016: 46-57) and inaccessibility to the general reader due to complex expression (Sprindyte 2006: $243,245,256)$. To an ordinary reader, Dirgèla's text was encoded with multilayered codes of philosophical questions and the semantics of language.

Having retreated to poetic polysemy due to political censorship and requirements by social realism, Lithuanian prose adopted and developed a multi-layered metaphor having an archetypal core. At the core, there was usually some chain of meanings unifying the cycles of Lithuanian history and survival contents, some words sharing the same root or preserving mythical content. One of the most notable examples of such poetry is a verse novel (which is a paradoxical choice even in terms of genre) Beads of Green Amber (1988) by poet Sigitas Geda, where the author, through the antiquity of the Lithuanian language and information in its semantic cores tells us about our perception of the world, our habits of talking about ourselves in the world, cycles of our behavior and customs, and a sense of time. On the one hand, this historical sense of the present in Geda's poetry, and not only his (we could name Martinaitis, Vaičiūnaitè, Bložè), brings us closer to folkloric wonders through playing with language, riddles and verbal dilemmas. 


\section{The Male and Female Version of History in Narratives}

We could say that the question of metaphysical history was left in the hands of a play of semantic associations, enigmatic parables and hidden links. Dirgèla, who was highly valued by a rather narrow circle of professionals, did not have a wide readership even despite considering a question that was so important to Lithuanian mentality, i.e. the kingdom of Lithuania. It was obvious that a difficult question was considered in a way that was too complex. Dirgèla's ambition itself to find the metaphysical root of Lithuanian history was nonetheless thrilling. In a way, his ambition demonstrated a volitional conception that simply did not match the chosen way of depiction. However, such were the lessons on Lithuanian prose learnt by Dirgèla as well as lessons on contemplating historical events.

The ambitions of Lithuanian prose poetry to explain the logic behind the events without a plot became a paradoxical challenge to the younger generation. Narrating self-reflection was suitable in Šerelytë's (b. 1970) prose, which highlighted the aspect of a passive victim in history. We could say that this prose revealed traumatic experiences of victims, women and children, who were trampled by aggressive ideology and lies, and psychological and physical coercion - women in gulags trying to survive with their children in a world that was hostile to them. The associative language of the novel did not intend to reveal all the truth of history, and thus did not cause conflict. Šerelytè speaks on behalf of the community and the voice she has chosen - that of a daughter, a mother, an orphan boy - embodies a generalised individual, a statistical average, even though they have features of a non-statistical character or fate.

In this respect, the younger generation's ambitious male prose was in dramatic conflict. At the beginning of independence, nobody spoke of any mental difference, but, with hindsight, the difference is quite obvious: prose written by men, even when it does not focus on historical discourse, for example Ričardas Gavelis (1950-2002) with his famous novel Vilnius Poker (1989), obviously places a stronger emphasis on an individual's, who is also male, responsibility for the decisions that determine what happens. In Gavelis's case, as well as in the already mentioned Kondrotas's case, we can talk about a version of a dystopia, of an alternative history, if not about magical realism, but in Gavelis's case this dystopia is a developed analysis of a totalitarian society, a careful study into reasons. This analysis is carried out only in order to find a rational answer amid collective processes produced in a completely irrational, unconscious way, which would bring rational comfort and would help to find a way out.

However, Gavelis's writing had nothing to do with Lithuanian prose poetry, and in some of his works he was even against it: for example, in his novel Memoirs of a Young Man (1991) he expresses negative opinion on the emotional and sensual writing prevalent in Lithuanian Soviet literature. This way of writing, 
however, could not change overnight, so it is unsurprising that the authors of the younger generation, on the one hand, did not fight against the prose poetry tradition and, on the other hand, pursued more ambitious goals by cherishing the tradition. One of them is the Lithuanian prose writer, playwright, film artist and journalist Marius Ivaškevičius, who gained fame through scandals. He became famous in 2002 after publishing his novel about the partisan war in Soviet Lithuania and thus causing a political scandal. Having named the protagonist after a famous partisan commander and by admitting that it was fiction and not reality at the end of the book, the young writer attempted to look at the reality of war through a young man's eyes, who had voluntarily chosen to dedicate his life to the fight for his country's freedom.

Male and female partisans portrayed by Ivaškevičius are the same as the dukes and their wives in Geda's novel Beads of Green Amber, people of nature and culture at the same time: they are sensual, full of desire to live, longing for bodily fulfillment, but at the same time their bodies have to face constant challenges of severe poverty in underground bunkers, dampness and the cold. By putting the characters of his novel into a place and time of highly limited existence, Ivaškevičius achieved an unexpected effect: he portrayed partisans as mortal human beings, who reach the peak of the meaning of their existence only by sacrificing their moral responsibilities. In Ivaškevičius's novel The Green, the time of history divides into short moments of partisans' lives and accentuates their sensual challenges: vigorous bodies in cramped darkness, a sense of bodily attraction, buckets of human waste being taken outside, and free-and-easy jokes in freedom.

The school of Lithuanian prose poetry, which is based on a sense of history created by strings of semantic associations and vertical metaphorical narrative and not the plot, prevented the general reader from understanding the work, so the novel about partisan war, the first of its kind, caused war in Lithuanian literature evaluation: relatives and friends of partisans who stayed alive and the partisans themselves filed a protest petition to the Lithuanian Writers Union and politicians also showed contempt for the novel: a well-known leader of Sajūdis (the Reform Movement of Lithuania) Vytautas Landsbergis published his particularly negative opinion on the novel, which was not even officially called a review, and ended a productive discussion by literary scholars, which was only about to begin, in his own way.

The novel was condemned without even understanding it well. It was condemned, but not forbidden. After the unfavourable reception in 2002, Ivaškevičius turned to playwriting and cinema and having written interesting plays, which were, by the way, based on similar vertical paradoxical poetics like in the novel, he became famous in the closest region. As far as I know from my 
colleague Tiina Kattel's presentation at a Lithuanian scholars' conference at Vilnius University, his play Expulsion is both known and valued in Estonia. Ivaškevičius's gift for playwriting was awarded the Golden Stage Cross of 2016 in Lithuania and the Golden Mask Award for Drama of 2017 in Russia.

During a quarter of a century, public Lithuanian critical discourse did not help the novel to reach its readers, and using political powers in the face of a work of art only prevented a normal discussion. In this way, literary criticism was not prohibited, but it was ignored by authorities who did not read it. However, attempts to understand what happened to this novel in the Lithuanian public sphere makes us look at the phenomenon of perception of history more carefully in the face of a new independence. Marius Ivaškevičius's book The Green has become probably the most read historical novel in contemporary Lithuanian literature only because of all the havoc.

But The Green is not the only historical discourse novel. There are a few more books by Lithuanian authors that reflect the matters of this period quite carefully such as the two big volumes about art, love and women in post-war Lithuania Maranta, 2015 and Maestro, 2019 by Birutė Jonuškaitè (b. 1959), or the novels about Lithuanian poets by Aldona Ruseckaite (b. 1950), which have been admired by the general reader. Historical thought also feeds art critic Kristina Sabaliauskaitë's (b. 1974) quill, who has gained great popularity; and the genuinely popular Undinè Radzevičiūtè (b. 1967), poet and prose writer Agnè Žagrakalytė (b. 1979), writer and translator Kazimiera Kazijevaitė (b. 1981) and writer Akvilina Cicenaite (b. 1979) take a closer look at the facts which are difficult to find in archives. All of these female writers focus on history, and action is a typical feature in their stories. A distinctive feature of their novels is the focus on the life of the little person, the family woman during the period of complex historical changes.

From all the mentioned women only Kristina Sabaliauskaite, who has a degree in Art History, chose the history of a noble family from Vilnius as the main subject of all her novels, the most famous of which is Silva Rerum (I, 2008; II, 2011; III, 2014; IV, 2016): the history starts in the $16^{\text {th }}$ century and slowly approaches the second half of the $18^{\text {th }}$ century and reveals, through the prism of family, the most important milestones in history: the baroque, the Enlightenment, the decadence of the Grand Duchy of Lithuania. The history of the noble family thus becomes not only a magnifying glass helping to understand the problems of the epoch in Lithuania, but also a family life saga revealing the existential contents of a human being in the epochs that are not only political or economic but also cultural. This novel was like rain after a period of drought to the Lithuanian reader and has been received as one of the most important works of the past decade. 
In the meantime, a diptych of novels Maranta (2015) and Maestro (2019) by Jonuškaite, a well-known writer, tells a story about fates of women of several generations and is an example of a common way of storytelling used by female authors to write about women's fates on the border of Lithuania and Poland. The fates are closely intertwined with all the tragic events of the $20^{\text {th }}$ century the period of the first independence, World War II, the border zone testing the limits of humanity and crossed by soldiers of different armies, the Holocaust, totalitarianism, and the fates of Poles in Lithuania, Lithuanians in Paris and Jews in Lithuania and Israel. Jonuškaitès women's fates are inseparable from men's fates; borderline geographical locations and experiences of historical events lead to the characters' ability to reflect on existential marginal experiences in conflicts of their own lives and lives of their families, their tribe and the people of their land.

The writer chooses characters who have found their vocation as an artist and summarizes the challenges to the $20^{\text {th }}$-century Lithuanian land by telling stories of their lives. Unlike Dirgèla or Ivaškevičius, Sabaliauskaite and Jonuškaite choose quite an intense palette of events and characters and do not avoid involving their characters in complex stories branching into even more storylines, but the quite vivid and rich language does not tend to turn into aposiopeses or strings of metaphors in the authors' works. Realism, which is rather psychologized, could not be called a type of prose poetry. The meeting of European and Chinese cultures and religions during a Spanish missionary's journey to the $18^{\text {th }}$-century China and lives of modern Chinese people in modern Europe as well as in Lithuania that the novel Fish and Dragons (2013) by Radzevičiūte tells us about are even further away from such prose. The voluminous novel portrays specific historical people and events, but it resists the temptation to use associations.

Ruseckaite's novels about well-known Lithuanian poets and writers of the $20^{\text {th }}$ century, i.e. which are half fictional, half documentary and have attracted a wide readership, perhaps do not fall into the category of stories about historical families. Ruseckaite, a long-time director of a literature museum, based her novels on and cited documentary material, but the main feature of her novels is focus on details of the living environment, empathy for writers' personalities, a deep knowledge of the reality of their lives and facts about their families and their works. Novels by the youngest generation of writers Forester's Daughter: Case F 117 (2013) by Žagrakalyte, Seven Generations (2016) by Kazijevaite and Story of Silence (2017) by Cicenaite tells stories about Lithuanian families of the past century under the conditions of totalitarianism, wars, occupation and freedom. All these novels focus on women's eyes, hearts and fates, embracing chronological events in their lives and land through the female line, i.e. great-grandmothers, grandmothers, mothers and daughters. 
The angle from which the story is viewed and told is not only sincere, but also historically based: during the important events in history, i.e. when men became partisans, fought in wars or went to prison, the survival of their families was in the hands of women. All the mentioned novels have an autobiographical core and we could say that these novels aim to restore national memory, explain the internal motives behind people's actions and rekindle the destroyed national dignity. In comparison to Ivaškevičius's novel The Green, novels written by female writers have no ambitions to gain a monopoly of the truth and only become part of the flow of the existing stories with their own version of a subjective truth. A small and insignificant but observant human being in the face of the great history becomes the reason these novels are interesting because by telling stories these novels fill the gaps in history that appeared in the face of wars, exile, and exodus. An empathetic relation to the environment and the surrounding people and a sensitive experience of the environment make us view these novels from a perspective that is beyond the tradition of poetic novels, and this is also something new.

Maybe we could talk about the different programs of male and female imagination, and probably not only in Lithuanian literature? Unfortunately, these novels meet favourable criticism only at book fairs, and in public discussions the focus is on matters that provoke these discussions. Thus we could point to the factors of publicity and marginality, which still center on the male version of the story, and the female one is avoided as it gives you a sense of insecurity and therefore does not attract the media's attention and is not so noticeable. Narrative in novels written by women is fluent and simple, but maybe too emotional. The novel The Green by Ivaškevičius, written in complex poetic language, may have revealed its problematic core as a double conflict: due to complex aesthetic solutions moral matters have become a problem; many readers do not read criticism and have not been able to understand such a novel on their own.

\section{Conclusions}

The evolution of modern Lithuanian prose, a spurt in which was seen during the decades of the first Lithuanian independence, was interrupted by World War II and five decades of totalitarian censorship terror. The essence of Soviet censorship obviated the need for narrating history as it ignored the facts of reality and forced authors to tell stories following an established ideological template. Lithuanian prose poetry emerged as a form of the Aesopian language, as an experiment performed by younger authors dreaming of independence. Talented authors helped to establish the experiment as an authority among professional critics and readers. Prose poetry with its polysemous and associative 
language returned to its Baltic and Indo-European self, a special historical quality which did not belong to the Soviet ideology or to the history of Soviet nations. Metaphorical, associative narrative made it possible to avoid storylines and direct links with the reality of the time. Within a few decades, Lithuanian prose poetry became a new tradition, a new school of Lithuanian prose, which remained dominant up until independence was regained as well as during its first two decades. However, after the argument for opposing censorship was lost, Lithuanian prose poetry lost its direction of development and, at the same time, began to question narratives which avoid storylines and are full of associations that puzzle readers. Paradoxically, Lithuanian prose which addressed the most delicate questions of history neither attracted the general reader nor had authority and even caused major conflicts in the general public. We could guess that the conception of such novels, which focused on authoritative people in history (Lithuanian nobles, politicians, soldiers, partisans), and associative narrative complicated the historical matters considered. Such consideration required clarity. On the other hand, prose by women, who attempted to depict lives of families at the periphery in terms of time and location, aided the development of a narrative with a storyline and told the reader about the real historical events.

\author{
Audinga Peluritytè \\ audinga.tikuisiene@flf.vu.lt \\ Vilnius University \\ LITHUANIA
}

\title{
References
}

Barthes, R., ed. 1991. Teksto malonumas. Transl. into Lith. by Galina Baužytė-Čepinskienè. Vilnius: Vaga.

Bartninkas, V., ed. 2016. Apie Karalystę (Petrą Dirgèlą kalbina Vilius Bartninkas). Vilnius: Naujasis Židinys - Aidai.

Beresnevičius, G., ed. 1990, Dausos. Vilnius: Gimtinè / Taura.

Beresnevičius, G., ed. 2008, Lietuviu religija ir mitologija. Vilnius: Tyto alba.

Berlin, I., ed. 1995, Vienove ir iqvairove. Transl. into Lith. by Alvydas Jokubaitis. Vilnius: Amžius.

Donskis, L., ed. 1994, Moderniosios sąmonès konfigūracijos: kultūra tarp mito ir diskurso. Vilnius: Baltos lankos.

Mickūnas, A., ed. 2012, Per fenomenologiją ị dzenbudizmą. Vilnius: Baltos lankos. 
History in Contemporary Lithuanian Literature

Sprindytė, J., ed. 2006, Prozos būsenos 1988-2005. Vilnius: Lietuvių literatūros ir tautosakos institutas.

Šilbajoris, R., ed. 1992. Netekties ženklai, Naujieji romanai Lietuvoje / Žvilgsnis į prozos dešimtmetị Lietuvoj: 1968-1978. Vilnius: Vaga.

Šilbajoris, R., ed. 1992. Netekties ženklai, Žmogus ir sąžinè Sovietų Sajungos pokario rusų ir lietuviu prozoje. Vilnius: Vaga.

Zalatorius, A., ed. 1988, Prozos gyvybe ir negalia. Vilnius: Vaga. 